\title{
Serological Screening Suggests Extensive Presence of Mycoplasma gallisepticum and Mycoplasma synoviae in Backyard Chickens in Southern Mozambique
}

\author{
Augusto Messa Júnior, ${ }^{1}$ Paula Taunde, ${ }^{1}$ Ana Felicidade Zandamela, ${ }^{2}$ \\ Alberto Pondja Junior, ${ }^{1}$ Abel Chilundo, ${ }^{1}$ Rosa Costa, ${ }^{2}$ and Custódio Gabriel Bila ${ }^{1}$ \\ ${ }^{1}$ Faculty of Veterinary Medicine, Eduardo Mondlane University, Av. de Moçambique Km 1,5, Maputo, Mozambique \\ ${ }^{2}$ Kyeema Foundation, Av. de Moçambique Km 1,5, Maputo, Mozambique
}

Correspondence should be addressed to Custódio Gabriel Bila; custodio.bila@uem.mz

Received 26 October 2016; Accepted 29 December 2016; Published 22 January 2017

Academic Editor: Antonio Ortega-Pacheco

Copyright ( 2017 Augusto Messa Júnior et al. This is an open access article distributed under the Creative Commons Attribution License, which permits unrestricted use, distribution, and reproduction in any medium, provided the original work is properly cited.

\begin{abstract}
A total of 459 serum samples from unvaccinated backyard chickens originating from 4 villages in Mandlakazi district, Southern Mozambique, were tested for the presence of Mycoplasma gallisepticum and Mycoplasma synoviae antibodies through commercial enzyme-linked immunoabsorbent assay [ELISA] kits. Anti-MG and anti-MS antibodies were detected in all villages surveyed and the overall seroprevalence was 48.8\% [95\% CI 39.1-57.8] and 84.5\% [95\% CI 76.8-90.4], respectively. The risk of being seropositive for both diseases was higher $[P<0.05]$ in Chidenguele village than other villages. It is concluded that MG and MS serum antibodies are present in backyard chickens.
\end{abstract}

\section{Introduction}

Indigenous chickens are local breeds of chickens [Gallus gallus domesticus] reared in rural areas of most parts of the world. Commonly, no proper housing is provided and very little food supplementation is offered. They move freely, scavenging for food and water [1]. Nevertheless, these chickens provide eggs and meat to most rural and many urban consumers. In Mozambique, like many sub-Saharan African countries, the productivity of indigenous chicken is hampered by several infectious diseases. Moreover, it is widely believed that indigenous chickens may act as potential reservoirs for important poultry diseases [2].

Infectious disease such as avian mycoplasmosis is mentioned as a potential constraint to the health status and productivity of domestic chickens. The disease is mainly caused by two pathogens: Mycoplasma gallisepticum [MG] and M. synoviae [MS]. It causes considerable economic losses in chicken through reduction of weight gain and meat quality, increase in feed conversion rate in broilers, severe drop in egg production in layers, or increase in embryo mortality in breeders [3-6].

MG is bacteria belonging to the class Molliculates, family Mycoplasmataceae, and is the most important economically significant mycoplasma pathogen of poultry. MG infections are also known as chronic respiratory disease [CRD] of chickens, infectious sinusitis of turkeys, and house finch conjunctivitis $[6,7]$. Birds of all age groups are more susceptible to this disease, but young birds are more prone to infection than adults [8]. MG may be transmitted horizontally from clinically infected or carrier birds and vertically through transovarian route $[6,9]$. Chickens may have not obvious symptoms or may exhibit coughing, sticky nasal discharge, difficulty breathing, swelling of the face, sneezing, foamy secretion in the eyes, and a drop in body weight as well $[9,10]$.

MS is the etiological agent of acute to chronic respiratory disease in chickens. Similarly to MG, MS transmission is also horizontal or vertical. Although slight rales may be present in birds with $M$. synoviae respiratory infection, usually no clinical signs are noticed. When present, they include 


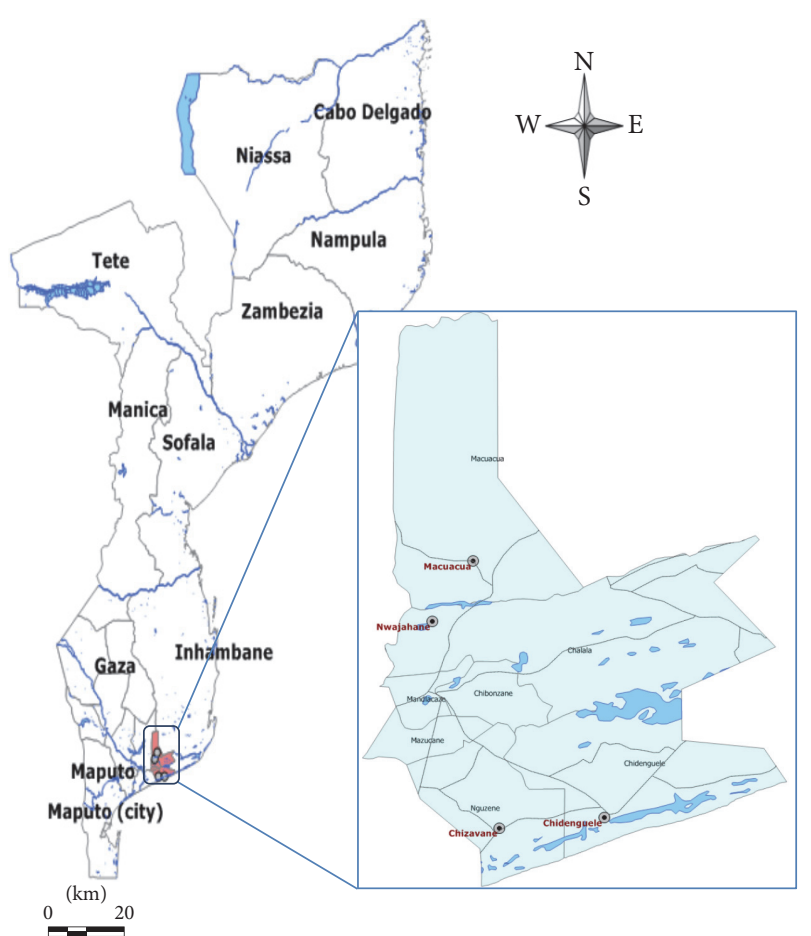

Mozambique administrative division

$\leftarrow$ Provinces

$\square$ Manjacaze administrative posts

-- Primary roads

- Study villages

m.n Rivers

Figure 1: Map of Mozambique indicating the location of the study site.

sneezing, nasal discharge, foam in the eye, rattle breathing, and swollen sinus. Morbidity is usually low to moderate with mortality of less than $10 \%[11,12]$.

Literature on the epidemiology of avian mycoplasmosis in backyard chickens in Africa is scanty, with few reports in Zimbabwe [13], Botswana [14], Benin [15], South Africa [16], and Ethiopia [17]. To our knowledge, there are no published reports of this disease in either commercial or backyard chickens in Mozambique. The objective of this study was to assess the presence of avian mycoplasmosis in backyard chickens in Southern Mozambique using serological approach.

\section{Materials and Methods}

2.1. Study Area. The study was carried out in four villages in Mandlakazi district: Chidenguele, Macuacua, Chizavane, and Nwadjahane (Figure 1). Mandlakazi district is part of Gaza Province in Southern Mozambique and is located between latitudes $44.04^{\circ} \mathrm{S}$ and $25.00^{\circ} \mathrm{S}$ and longitudes $33.56^{\circ} \mathrm{E}$ and $34.28^{\circ} \mathrm{E}$. It comprises an area of $3.797 \mathrm{~km}^{2}$ [18] with an estimated population of 175.607 inhabitants [19]. It is bordered in the north by Chibuto and Panda districts, in the south by Indian ocean, in the east by Zavala and Inharrime districts, and in the west by Chibuto and Xai-Xai.

The district is characterized by a dry inland and humid climate on the coast with rainfall varying from $400 \mathrm{~mm}$ to $950 \mathrm{~mm}$ per year, occurring from November to March, and with average monthly temperatures of 17 to $28^{\circ} \mathrm{C}$ [18]. It is administratively divided into seven areas (Chalala, Chibonzane, Chidenguele, Macuacua, Mazucane, Nguzene, and Manjacaze) and the mixed agriculture (livestock and crop) is the most important economic activity [18].

2.2. Study Design and Sampling. The study was conducted from January to March 2016, using a cross-sectional design. Willing and commitment with the objective of the study were the eligibility criteria for a villager to participate in the study. The sampling frame was all chicken keepers in the selected villages with chickens older than 2 months. Sample size calculation was done using the formula $n=\left[Z \alpha^{2} *\right.$ $p * q / L^{2}$ ], where $n=$ sample size required; $Z \alpha=1.96$ is the value required for confidence of $95 \%$; $p$ is the a priori estimate of the prevalence; $q=1-p$, the complementary of prior estimate, and $L=5 \%$, the precision of estimate, given by Naing et al. [20]. A priori estimate of the prevalence of $50 \%$ was used, once there were no previous studies regarding avian mycoplasmosis. A sample size of 459 was computed.

2.3. Blood Sampling and Serology. Approximately $2.5-3 \mathrm{~mL}$ of blood was collected from brachial vein per each chicken into disposable syringes, as described by Kelly and Alworth [21]. Then, the syringes were left horizontally and then vertically for the serum to ooze out. Serum was then collected in $2 \mathrm{~mL}$ cryovial tubes and kept at $-20^{\circ} \mathrm{C}$ until testing.

Serum samples were analysed using commercial ELISA kits for the presence of anti-MG antibodies [ProFLOK ${ }^{\circledR}$ Mycoplasma gallisepticum Antibody Test Kit, Synbiotics Corp., San Diego, CA, item number 96-6533] and anti-MS antibodies [ProFLOK ${ }^{\circledR}$ Mycoplasma synovie Antibody Test Kit, Synbiotics Corp., San Diego, CA, item number 96-6536], according to the manufacturer's instructions. These commercial kits are based on the principle of indirect ELISA. The sample and control OD values were read using an automated microplate reader [EL $\times 800$, BIOTEK, Instruments Inc., Winooski, VT] at $405 \mathrm{~nm}$. For each sample, the sample-to-positive $[S / P]$ ratios were calculated from $\mathrm{OD}$ values by the formula:

$$
\begin{aligned}
& S / P \text { ratio } \\
& =\frac{[\text { OD sample }- \text { negative control mean OD }]}{[\text { positive control mean OD }- \text { negative control mean OD] }} ;
\end{aligned}
$$

see [22].

2.4. Data Analysis. Data were entered in MS Excel spreadsheet and exported to STATA $^{\circledR}$ version 12.1 [Stata IC 12.1 for Windows], software for analysis. Prevalence data were analysed using chi-square test $\left[\chi^{2}\right.$-test $]$. Logistic regression models were used to compute odds ratios [OR] to identify the risk for being seropositive as dichotomous dependent 
TABLE 1: Seroprevalence of MG and MS in unvaccinated backyard chickens in Southern Mozambique.

\begin{tabular}{lcrr}
\hline Villages & \multicolumn{2}{c}{ Number of serum samples } & \multicolumn{2}{c}{ Seroprevalence [\%, exact 95\% CI] } \\
\hline Nwadjahane & 103 & $37.8[28.5-47.9]^{\mathrm{a}}$ & $89.3[81.7-94.5]^{\mathrm{a}}$ \\
Macuacua & 106 & $48.1[38.3-58.0]^{\mathrm{a}}$ & $77.3[68.2-84.9]^{\mathrm{b}}$ \\
Chizavane & 128 & $43.8[35.0-52.8]^{\mathrm{a}}$ & $79.6[71.7-86.3]^{\mathrm{b}}$ \\
Chidenguele & 122 & $63.9[54.7-72.4]^{\mathrm{b}}$ & $91.8[85.4-95.8]^{\mathrm{a}}$ \\
Total & 459 & $48.8[39.1-57.8]$ & $84.5[76.8-90.4]$ \\
\hline
\end{tabular}

a,b Villages with different superscript differ significantly $(P<0.05)$.

variable and independent variable [location]. In all chisquare tests, a probability level of $P<0.05$ was considered statistically significant.

\section{Results and Discussion}

The backyard chickens tested in this study had no previous history of avian mycoplasmosis vaccination since this practice is not routine in the poultry industry in Mozambique. Hence, the presence of antibodies to MG and MS in all surveyed villages was considered clear evidence that the birds have been naturally exposed to those two infectious agents.

The MG prevalence observed in this study was $48.8 \%$, ranging from $28.5 \%$ to $72.4 \%$ (Table 1 ). Our finding constitutes the first report of MG prevalence in poultry in Mozambique and is approximately in agreement with report from Zimbabwe (<33\%) [13]. Higher prevalence was reported in backyard chickens in Benin (62\%) [15], Botswana (57.8\%) [14], South Africa (63\%) [16], Ecuador (73\%) [22], Bangladesh (58.9\%) [23], Argentina (68.6-100\%) [24], Ethiopia (67.7\%) [17], and Brazil (53.3\%) [25].

Our study also revealed that the prevalence of MS antibodies was generally high, around $84.5 \%$, and varied from $68.2 \%$ to $95.8 \%$ (Table 1). Our results are the first documentation of the presence of MS in backyard chickens in Mozambique and are consistent with seroprevalence in fancy breeding chickens of $75 \%$ in Switzerland [26], where the management system is equivalent to the one in backyard poultry flocks. Lower prevalence was reported in Botswana (40.99\%) [14] and Paraguay (53\%) [27].

In the studied villages, the backyard chickens were neither given any immunizations nor afforded treatments, which make them intrinsically sensitive to numerous infectious diseases. These chickens were on poor plane of nutrition and were kept in flocks of mixed ages, with susceptible chicks in contact with adults that are potential reservoirs for diseases. Furthermore, they were allowed to move freely, scavenging for food and water in the crop fields, lakes, and rivers, habitats that attract large numbers of wild birds. These epidemiology factors may have contributed to the natural exposure of the birds and could explain the high prevalence detected for both MG and MS, as reported elsewhere [28].

In terms of geographical variations, the seroprevalence of both MG and MS was higher in Chidenguele than other three villages with $63.9 \%$ and $91.8 \%$, respectively (Table 1 ). Why the seroprevalence is higher in this village compared to other villages is unknown. However, it could be related to the proximity of Chidenguele village to the main national road [N1], where there is huge influx of people and animals moving from south to north regions of the country and vice versa.

\section{Conclusions}

There was a serological evidence of the presence of $\mathrm{MG}$ and MS in backyard chickens in Mandlakazi district of Mozambique.

\section{Competing Interests}

The authors declare that there is no conflict of interests regarding the publication of this paper.

\section{Acknowledgments}

The authors are thankful to the chicken farmers that accepted to participate in this study. Fundo Nacional de Investigação, Mozambique (GRANT FV5/2014), and Centre for Coordination of Agricultural Research and Development for Southern Africa (CCARDESA) (Grant CPRJ/INT/WB/CFP1/14/03) funded this research project.

\section{References}

[1] R. R. Say, Manual of Poultry Production in the Tropics, Cab International, Wallingford, UK, 1987.

[2] K. Bouzoubaa, K. Lemainguer, and J. G. Bell, "Village chickens as a reservoir of Salmonella pullorum and Salmonella gallinarum in Morocco," Preventive Veterinary Medicine, vol. 12, no. 1-2, pp. 95-100, 1992.

[3] L. Stipkovits and I. Kempf, "Mycoplasmoses in poultry," Revue Scientifique et Technique, vol. 15, pp. 1495-1525, 1996.

[4] J. M. Bradbury, "Avian mycoplasmosis," in Poultry Diseases, J. M. Bradbury, Ed., pp. 178-193, W.B. Saunders Company, Iowa City, Iowa, USA, 2001.

[5] J. D. Evans, S. A. Leigh, S. L. Branton, S. D. Collier, G. T. Pharr, and S. M. D. Bearson, "Mycoplasma gallisepticum: current and developing means to control the Avian pathogen," The Journal of Applied Poultry Research, vol. 14, no. 4, pp. 757-763, 2005.

[6] D. H. Ley, "Mycoplasma gallisepticum infection," in Disease of Poultry, A. M. Fadly, J. R. Gilson, L. R. McDougald, L. K. Nolan, and D. E. Swanye, Eds., pp. 807-834, Iowa State University Press, Ames, Iowa, USA, 2008. 
[7] S. H. Kleven, "Mycoplasmas in the etiology of multifactorial respiratory disease," Poultry Science, vol. 77, no. 8, pp. 1146-1149, 1998.

[8] S. Seifi and M. R. Shirzad, "Seroprevalence and risk factors of Mycoplasma gallisepticum infection in iranian broiler breeder farms," International Journal of Animal and Veterinary Advances, vol. 4, pp. 45-48, 2012.

[9] D. H. Ley, "Mycoplasma gallisepticum infection," in Disease of Poultry, B. W. Calnek, H. J. Barnes, C. W. Beard, L. R. McDougald, and Y. M. Saif, Eds., pp. 722-744, Iowa State University Press, Ames, Iowa, USA, 2003.

[10] S. L. Hennigan, J. D. Driskell, N. Ferguson-Noel et al., "Detection and differentiation of avian mycoplasmas by surfaceenhanced raman spectroscopy based on a silver nanorod array," Applied and Environmental Microbiology, vol. 78, no. 6, pp. 1930-1935, 2012.

[11] S. H. Kleven, "Mycoplasma synoviae infection," in Disease of Poultry, Y. M. Saif, H. J. Barnes, J. R. Glisson, A. M. Fadly, L. R. McDougald, and D. E. Swayne, Eds., pp. 756-765, University Press, Ames, Iowa, USA, 2003.

[12] S. H. Kleven, "Poultry: mycoplasmosis," in The Merck Veterinar Manual, C. M. Kahn, Ed., pp. 2242-2246, Merck \& Co., Whitehouse Station, NJ, USA, 2005.

[13] P. J. Kelly, D. Chitauro, C. Rohde et al., "Diseases and management of backyard chicken flocks in Chitungwiza, Zimbabwe," Avian Diseases, vol. 38, no. 3, pp. 626-629, 1994.

[14] E. Z. Mushi, M. G. Binta, R. G. Chabo, M. Mathaio, and R. T. Ndebele, "Detection of Mycoplasma gallisepticum and Mycoplasma synoviae antibodies in the sera of indigenous chickens by rapid serum agglutination test at Mmopane, Gaborone, Botswana," Onderstepoort Journal of Veterinary Research, vol. 66, no. 4, pp. 333-334, 1999.

[15] C. A. A. M. Chrysostome, J. G. Bell, F. Demey, and A. Verhulst, "Sero prevalences to three diseases in village chickens in Benin," Preventive Veterinary Medicine, vol. 22, no. 4, pp. 257-261, 1995.

[16] M. M. O. Thekisoe, P. A. Mbati, and S. P. R. Bisschop, "Diseases of free-ranging chickens in the Qwa-Qwa district of the northeastern Free State province of South Africa," Journal of the South African Veterinary Association, vol. 74, no. 1, pp. 14-16, 2003.

[17] H. Chaka, F. Goutard, S. P. R. Bisschop, and P. N. Thompson, "Seroprevalence of Newcastle disease and other infectious diseases in backyard chickens at markets in Eastern Shewa zone, Ethiopia," Poultry Science, vol. 91, no. 4, pp. 862-869, 2012.

[18] Ministério de Adiministração Estatal, Perfil do Distrito de Mandlakaze, 2005.

[19] INE, Estatística do Distrito de Mandlakaze, 2012.

[20] L. Naing, T. Winn, and B. N. Rusli, "Practical issues in calculating the sample size for prevalence studies," Archives of Orofacial Sciences, vol. 1, pp. 9-14, 2006.

[21] L. M. Kelly and L. C. Alworth, "Techniques for collecting blood from the domestic chicken," Lab Animal, vol. 42, no. 10, pp. 359361, 2013.

[22] S. M. Hernandez-Divers, P. Villegas, F. Prieto et al., "A survey of selected avian pathogens of backyard poultry in northwestern Ecuador," Journal of Avian Medicine and Surgery, vol. 20, no. 3, pp. 147-158, 2006.

[23] A. J. Sikder, M. A. Islam, M. M. Rahman, and M. B. Rahman, "Seroprevalence of Salmonella and Mycoplasma gallisepticum infection in the six model breeder poultry farms at Patuakhali district in Bangladesh," International Journal of Poultry Science, vol. 4, no. 11, pp. 905-910, 2005.
[24] J. Xavier, D. Pascal, E. Crespo, H. L. Schell, J. A. Trinidad, and D. J. Bueno, "Seroprevalence of Salmonella and Mycoplasma infection in backyard chickens in the state of Entre Ríos in Argentina," Poultry Science, vol. 90, no. 4, pp. 746-751, 2011.

[25] C. B. C. Silva, W. F. Chagas, R. F. Santos, L. R. Gomes, M. R. Ganda, and A. M. C. Lima, "Seroprevalence of salmonella and mycoplasma in commercial broilers, backyard chickens, and spent hens in the region of triângulo mineiro, State of Minas Gerais, Brazil," Revista Brasileira de Ciencia Avicola, vol. 17, no. 1, pp. 57-62, 2015.

[26] C. Wunderwald and R. K. Hoop, "Serological monitoring of 40 Swiss fancy breed poultry flocks," Avian Pathology, vol. 31, no. 2, pp. 157-162, 2002.

[27] K. Suzuki, J. Origlia, F. Álvarez et al., "Relative risk estimation for Mycoplasma synoviae in backyard chickens in Paraguay," International Journal of Poultry Science, vol. 8, no. 9, pp. 842847, 2009.

[28] S. M. Hernandez-Divers, P. Villegas, C. Jimenez et al., "Backyard chicken flocks pose a disease risk for neotropic birds in Costa Rica," Avian Diseases, vol. 52, no. 4, pp. 558-566, 2008. 

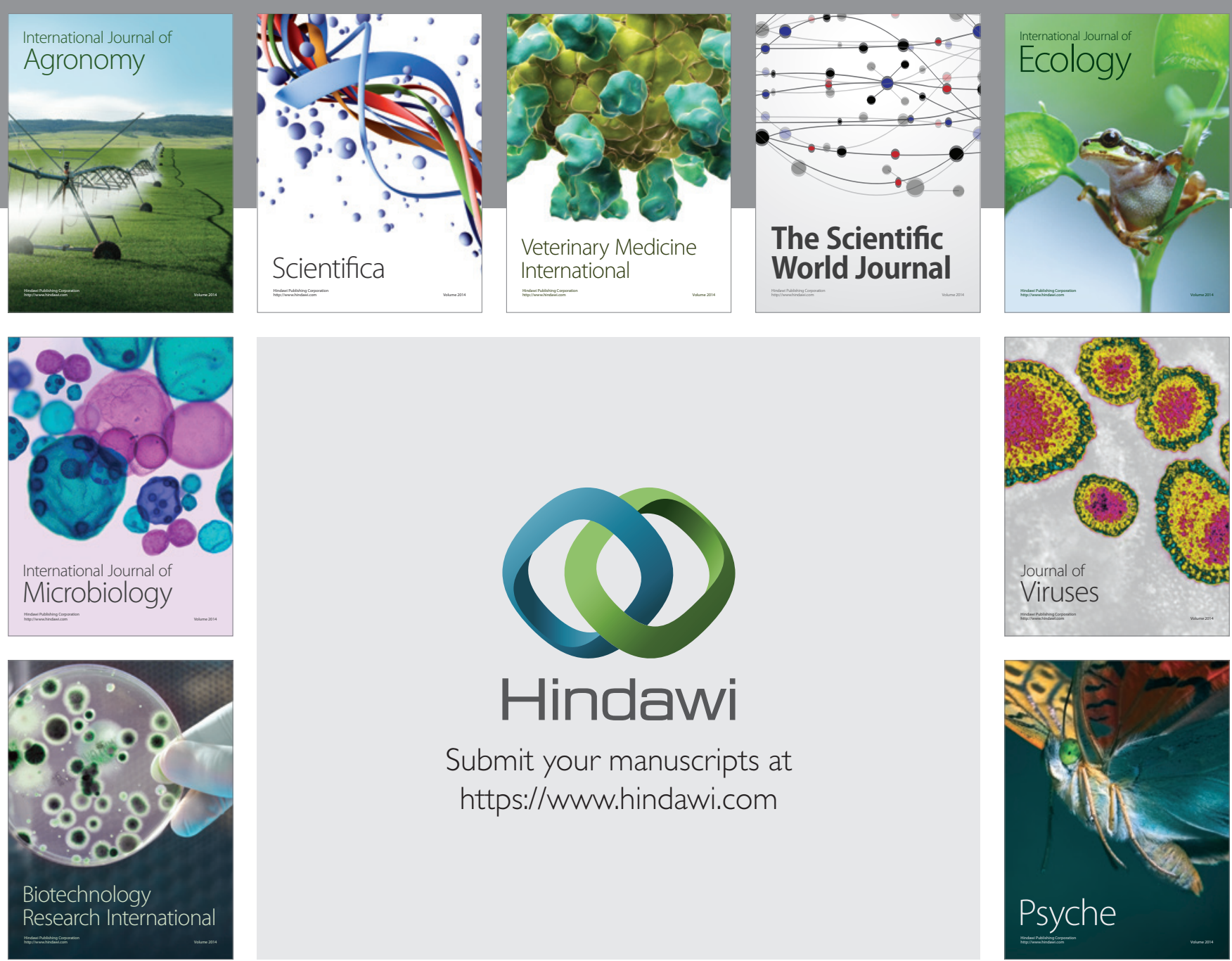

\section{Hindawi}

Submit your manuscripts at

https://www.hindawi.com
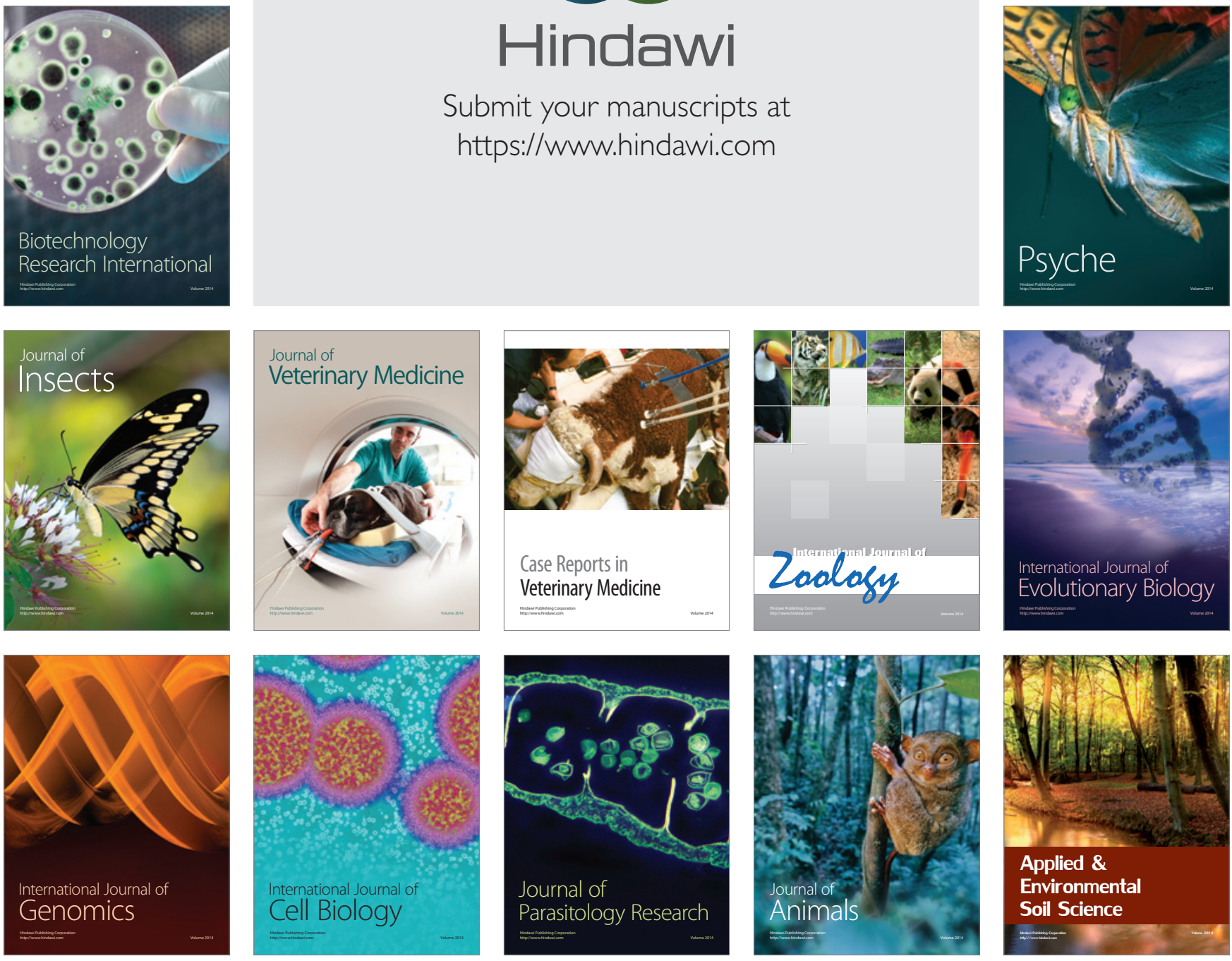